\title{
Changes in Alveolar and Cisternal Compartments Induced by Milking Interval in the Udder of Dairy Ewes
}

\author{
V. Castillo, ${ }^{*}$ X. Such, ${ }^{*}$ G. Caja, ${ }^{, 1}$ A. A. K. Salama, ${ }^{*} \dagger$ E. Albanell, ${ }^{*}$ and R. Casals ${ }^{*}$ \\ *Grup de Recerca en Remugants, Departament de Ciència Animal i dels Aliments, Universitat Autònoma de Barcelona, 08193 Bellaterra, Spain \\ †Sheep and Goat Research Department, Animal Production Research Institute, 4 Nadi El-Said, 12311 Dokki, Giza, Egypt
}

\begin{abstract}
The aim of this work was to evaluate the effects of milking interval $(4,8,12,16,20$, and $24 \mathrm{~h})$ on cisternal size and milk partitioning (cisternal and alveolar) in the udders of dairy ewes. Twenty-four dairy ewes (Manchega, $\mathrm{n}=12$; Lacaune, $\mathrm{n}=12$ ) were used in a 2-wk experiment during mid-lactation. Cisternal and alveolar milk yields were measured and milk samples from each udder fraction were collected for analysis. Cisternal milk was obtained after i.v. injection of an oxytocin receptor antagonist, and alveolar milk was obtained after i.v. injection of oxytocin. Enlargement of the cisternal compartment due to milking intervals was measured by ultrasonography for each half udder. Volumes of cisternal and alveolar milk differed according to breed, being greater in Lacaune $(888 \pm 43$ and $338 \pm$ $25 \mathrm{~mL}$, respectively) than in Manchega ewes (316 \pm 43 and $218 \pm 25 \mathrm{~mL}$, respectively). Alveolar milk increased linearly to $16 \mathrm{~h}$ in Manchega and $20 \mathrm{~h}$ in Lacaune and remained constant thereafter. Cisternal milk accumulated linearly to 24 -h milking intervals in both breeds. Cisternal area (values per udder half) increased as milking interval increased, reaching a plateau at $20 \mathrm{~h}$ in Manchega $\left(21 \pm 1 \mathrm{~cm}^{2}\right)$ and $16 \mathrm{~h}$ in Lacaune $(37 \pm 1$ $\mathrm{cm}^{2}$ ). Correlation between cisternal area and cisternal milk was the greatest at $8 \mathrm{~h}$ (Manchega: $\mathrm{r}=0.70$ and Lacaune: $r=0.56$ ). Cisternal area correlated with total milk $(r=0.80)$. Milk fat content varied markedly with milking intervals, increasing in alveolar milk (until 12 $\mathrm{h}$ in Manchega, $8.90 \pm 0.18 \%$; and $20 \mathrm{~h}$ in Lacaune, 8.67 $\pm 0.19 \%)$ and decreasing until $24 \mathrm{~h}$ in cisternal milk (5.74 $\pm 0.29 \%$ and $4.85 \pm 0.29 \%$, respectively). Milk protein content increased in alveolar milk until $24 \mathrm{~h}$ (Manchega, $6.46 \pm 0.11 \%$; Lacaune, $5.95 \pm 0.11 \%$ ), but did not vary in cisternal milk. Milk lactose content only decreased at the 24-h milking interval in the cisternal milk of Manchega ewes (4.60 $\pm 0.04 \%)$. In conclusion, our results suggest that cisterns play an important role
\end{abstract}

Received February 13, 2008.

Accepted May 23, 2008.

${ }^{1}$ Corresponding author: gerardo.caja@uab.es in accommodating secreted milk during extended milking intervals. Thus, long milking intervals could be a recommended strategy for large-cisterned dairy sheep. Evidence indicates that ultrasonography provides accurate estimations of udder cistern size and could be used as an indicator for selecting large-cisterned dairy ewes.

Key words: ultrasonography, milking frequency, cisternal milk, dairy sheep

\section{INTRODUCTION}

Secreted milk in dairy ruminants is stored extracellularly within 2 anatomical udder compartments: alveolar (alveolar lumen and small ducts) and cisternal (large ducts and gland and teat cisterns). Milk partitioning between both compartments varies according to species, breed, age, stage of lactation, and milking interval (Bruckmaier et al., 1997; Davis et al., 1998; Salama et al., 2004), and helps explain the change of milk yield and milk composition that occurs when the milking interval is extended to $24 \mathrm{~h}$. Milk yield and milk composition changes for each compartment at different milking intervals were reported by McKusick et al. (2002) in dairy ewes. Cows and goats that store greater proportions of milk in the gland cistern produce more milk and are more able to tolerate extended milking intervals than those that store a greater proportion of milk in the alveolar compartment (Davis et al., 1998; Salama et al., 2004). Dewhurst and Knight (1994) indicated that cows with small cisterns had a greater response when milking frequency increased from twice- to thrice-daily milking. Moreover, stripping can be suppressed in large-cisterned ewes with few effects on milk yield and a dramatic reduction in milking time (Labussière, 1988).

Ultrasonography allows the noninvasive exploration of the internal structure of the mammary gland and has been used for measuring cisternal size in ewes (Bruckmaier and Blum, 1992; Ruberte et al., 1994; Nudda et al., 2000), goats (Bruckmaier and Blum, 1992; Salama et al., 2004), and cows (Bruckmaier and Blum, 1992; Ayadi et al., 2003). Several studies 
have shown that ultrasonography could be useful for studying the udder changes that occur to accommodate milk during different milking intervals and after milk letdown in cows (Ayadi et al., 2003, Caja et al., 2004) and goats (Salama et al., 2004). However, as far as we know, ultrasonography has not been used to evaluate cisternal size changes when different milking intervals are performed in dairy ewes.

The main objective was to study the effect of milking intervals on cisternal size and milk partitioning in the udder of 2 dairy ewe breeds (Manchega and Lacaune) differing in lactational performance. Composition of milk obtained from each udder compartment was evaluated at different milking intervals. The experiment allowed validation of the udder scanning methodology in ewes of different cistern sizes and at different intervals after milking.

\section{MATERIALS AND METHODS}

The experimental procedures and animal care conditions were approved by the Ethical Committee of Animal and Human Experimentation of the Universitat Autònoma de Barcelona (reference CEEAH 02/410).

\section{Animals and Management Conditions}

Twenty-four adult lactating dairy ewes of 2 breeds (Manchega, $\mathrm{n}=12,70.2 \pm 2.4 \mathrm{~kg}$ of BW; Lacaune, $\mathrm{n}=$ $12,75.5 \pm 2.2 \mathrm{~kg}$ of BW) with symmetrical and healthy udders (SCC, $64 \pm 48 \times 10^{3}$ cells $/ \mathrm{mL} ;<5 \mathrm{cfu} / \mathrm{mL}$ ) from the experimental farm of SGCE (Servei de Granges i Camps Experimentals) of the Universitat Autònoma de Barcelona in Bellaterra (Spain) were used in a short-term experiment performed at wk 11 and 16 of lactation.

Ewes had similar stage of lactation $(70 \pm 3$ DIM) and milk yield by breed (Manchega, $1.11 \pm 0.09 \mathrm{~L} / \mathrm{d}$; Lacaune, $2.32 \pm 0.11 \mathrm{~L} / \mathrm{d}$ ) in the week before (wk 10) the start of the experiment. Ewes were allocated at wk 10 and 15 of lactation into 6 groups of 4 ewes each (Manchega, $\mathrm{n}=2$; Lacaune, $\mathrm{n}=2$ ), and were housed indoors, fed a dehydrated forage-based diet, and managed as described previously by Castillo et al. (2008).

Ewes were milked in a double-12 stall parallel milking parlor (Westfalia Surge Ibérica, Granollers, Spain), set to $42 \mathrm{kPa}, 120$ pulses/min, and $50 \%$ pulsation ratio, and equipped with recording jars and low milk pipeline. Before the experiment, animals were milked twice daily (0800 and $1800 \mathrm{~h}$ ), and the milking included machine milking (without udder preparation or teat cleaning), machine stripping, and teat dipping in an iodine solution (P3-Ioshield, Ecolab Hispano-Portuguesa, Barcelona, Spain).

\section{Experimental Procedure}

The experiment consisted of a crossover with 6 milking intervals $(4,8,12,16,20$, and $24 \mathrm{~h})$ at random, replicated at wk 11 and 16 of lactation. Milking interval schedule during each experimental week was applied successively (total length $84 \mathrm{~h}$ ) without any period of washing-out between milking intervals. Carryover effects between milking intervals were reduced by randomizing the milking order of ewe groups and by removing alveolar milk at milk fraction collection (Castillo et al., 2008). The experiment started $(0 \mathrm{~h})$ after complete udder emptying by machine milking with the help of an i.v. injection of oxytocin (2 IU/ewe; Veterin Lobulor, Laboratorios Andreu, Barcelona, Spain) to remove residual milk. Thereafter, 1 of the 6 milking interval treatments was randomly applied, and the same udder emptying procedure was repeated for each milking interval treatment.

\section{Scanning Methodology}

To prevent undesired milk letdown during scanning and to enable recording of cisternal and alveolar milk fractions separately, each ewe was injected i.v. with $0.8 \mathrm{mg} / \mathrm{ewe}$ of atosiban, an oxytocin receptor blocking agent (Tractocile $7.5 \mathrm{mg} / \mathrm{mL}$, Ferring, Madrid, Spain) while in its pen before being taken to the milking parlor. Cisternal size was evaluated for each half udder by measuring cisternal area by ultrasonography. Ultrasonography was conducted using a real-time B-mode ultrasonograph (Ultra Scan 900, Ami Medical Alliance Inc., Montreal, Canada) equipped with a $5-\mathrm{MHz}$ sectorial probe $\left(2 \mathrm{~dB}\right.$ power, $80^{\circ}$ scanning angle, $0.5 \mathrm{~mm}$ axial and $1.5 \mathrm{~mm}$ lateral resolution). Exploration depth was $14 \mathrm{~cm}$. The probe was placed directly against the upper part of the medium suspensory ligament, caudally to the udder, and between the inguinal lymph nodes (Ruberte et al., 1994; Rovai, 2001) using the teat as scan axis. Contact gel (Geleco, Laboratorios Carreras, Barcelona, Spain) was applied to udder skin to exclude air between probe and udder. Scans were done for each udder half and transferred to a personal computer for image analysis. Cisternal area was calculated in triplicate for each scan using image treatment software (MIP4 Advanced System, Microm España, Barcelona, Spain). Area in pixels was converted to centimeters squared using a conversion rate of 1,024 pixels $/ \mathrm{cm}^{2}$.

As the calculated half-life of atosiban is approximately 18 min (Wellnitz et al., 1999), a single dose was sufficient to prevent milk letdown during the time that ewes were being moved to the milking parlor (approximately $4 \mathrm{~min}$ ), having scans performed on both half udders (approximately $5 \mathrm{~min}$ ), and having cisternal 
milk evacuated by machine milking ( $<2 \mathrm{~min})$. Approximately 20 min after the atosiban injection, ewes were injected i.v. with 2 IU of oxytocin and machine-milked to obtain letdown alveolar milk.

\section{Sampling and Analyses}

Milk volume was recorded and sampled for each milking and udder fraction. Samples of approximately $100 \mathrm{~mL}$ were preserved with potassium dichromate $(0.3 \mathrm{~g} / \mathrm{L})$ at $4^{\circ} \mathrm{C}$ until analysis of milk composition. Unhomogenized milk samples were analyzed with a nearinfrared spectrometer (InfraAlyzer-450, Bran+Luebbe, Nordersted, Germany) for content of total solids, fat, CP $(\mathrm{N} \times 6.38)$, true protein, casein, and lactose. Samples for SCC were preserved with an antimicrobial tablet (Bronopol, Broad Spectrum Micro-tabs II, D\&F Control Systems Inc., San Ramon, CA) and kept at $4^{\circ} \mathrm{C}$ until analysis. The SCC was determined in the DHI Laboratory of Catalonia (Allic, Cabrils, Barcelona, Spain) using an automatic cell counter (Fossomatic 5000, Foss Electric, Hillerød, Denmark) specifically calibrated for sheep milk.

\section{Statistical Analysis}

Results were analyzed by the PROC MIXED procedure for repeated measurements of SAS (version 8.2, SAS Institute Inc., Cary, NC). The mixed model used included the fixed effects of milking interval $(4,8,12$, 16, 20, and $24 \mathrm{~h}$ ), breed (Manchega and Lacaune), milk fraction (cisternal and alveolar), group (1 to 6), period (wk 11 and 16), and order of treatment application (first to sixth); the random effect of animal nested within group and breed; the interactions breed by milking interval, milk fraction by milking interval, period by milking interval, breed by milk fraction, and period by milk fraction; and residual error. Differences between least squares means were determined with the PDIFF test of SAS and significance was declared at $P<0.05$. Pearson correlation coefficients between measurements were calculated. Significance was declared as $P<0.05$ unless otherwise indicated.

\section{RESULTS AND DISCUSSION}

\section{Milk Volumes and Milk Partitioning in the Udder}

Volumes of cisternal and alveolar milk were greater $(P<0.001)$ in Lacaune compared with Manchega ewes (Lacaune vs. Manchega: cisternal milk 888 vs. $316 \mathrm{~mL}$; SEM, 60 mL; alveolar milk, 338 vs. 218 mL; SEM, 36 $\mathrm{mL}$, respectively). Experimental period affected $(P<$ $0.001)$ volumes of cisternal and alveolar milk in both breeds, being greater $(P<0.05)$ in the first period (wk
11) than in the second (wk 16). Mean values for cisternal milk (680 vs. $525 \mathrm{~mL}$; SEM, $24 \mathrm{~mL}$ ) and alveolar milk (300 vs. $256 \mathrm{~mL}$; SEM, $13 \mathrm{~mL}$ ) decreased 23 and $15 \%$, respectively.

Volumes of cisternal and alveolar milk varied $(P<$ 0.001 ) according to milking interval (Figure 1). Cisternal milk increased $(P<0.05)$ linearly until $24 \mathrm{~h}$ of udder filling (Figure 1a) in both breeds. Alveolar milk increased linearly $(P<0.05)$ until $16 \mathrm{~h}$ in Manchega and $20 \mathrm{~h}$ in Lacaune dairy ewes (Figure 1b). Thus, the alveolar compartment saturated earlier than the cisternal compartment in both breeds. These results agree with the pattern of milk accumulation for extended milking intervals in dairy ewes (McKusick et al., 2002) and in dairy goats (Salama et al., 2004) whose alveolar milk reached plateaus 20 and $16 \mathrm{~h}$ after milking, respectively. These authors reported that cisternal milk increased continuously until $24 \mathrm{~h}$, in both ewes and goats.

Accumulation pattern of cisternal and alveolar milk volumes during the 4 - to 24 -h milking interval was studied through regression analysis. The best determination coefficients were obtained for linear regression, the equations $(\mathrm{y}, \mathrm{mL}$ of milk fraction; $\mathrm{x}, \mathrm{h}$ of milking interval; $P<0.001)$ being:

Cisternal milk $(\mathrm{mL})$ :

$$
\begin{aligned}
& \text { Manchega }\left(R^{2}=0.98\right), y=23.2 x, \\
& \text { Lacaune }\left(R^{2}=0.99\right), y=64.5 x
\end{aligned}
$$

Alveolar milk (mL):

$$
\begin{aligned}
& \text { Manchega }\left(R^{2}=0.97\right), y=92+9.0 x \\
& \text { Lacaune }\left(R^{2}=0.99\right), y=153+13.2 x
\end{aligned}
$$

The analysis of the regression lines showed that the dose of oxytocin administered was not enough to evacuate completely the alveolar compartment. The volume of milk left in the compartment, $66 \%$ greater in Lacaune than Manchega, agreed with the expected size of the alveoli population in each breed. Lollivier and Marnet (2005) showed differences between cows in the dose necessary to induce milk ejection ( 0.25 to $4 \mathrm{IU})$, but the doses used by these researchers were markedly lower (0.005 to $0.008 \mathrm{UI} / \mathrm{kg}$ of $\mathrm{BW}$ for a $500-\mathrm{kg}$ cow) than in our case. Thus, dose of oxytocin used (2 IU/ewe) was considered to be supraphysiological for both breeds (0.029 IU/kg of BW for a 70-kg ewe) and did not limit the contractive response of the alveoli. Differences in udder morphology between the 2 breeds, Lacaune having larger and baggier udders than Manchega (Rovai, 2001), may explain the differences observed in the 


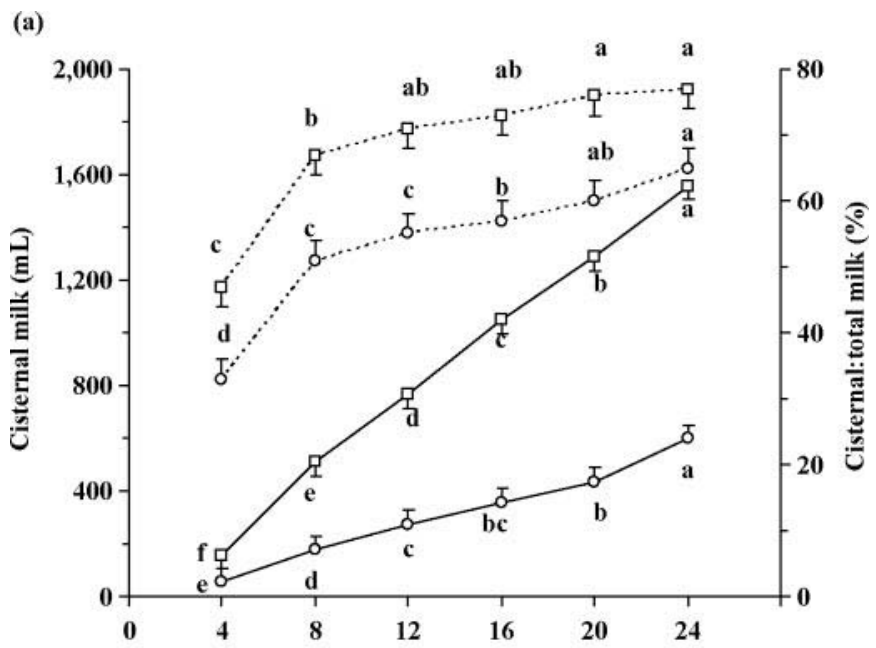

(b)

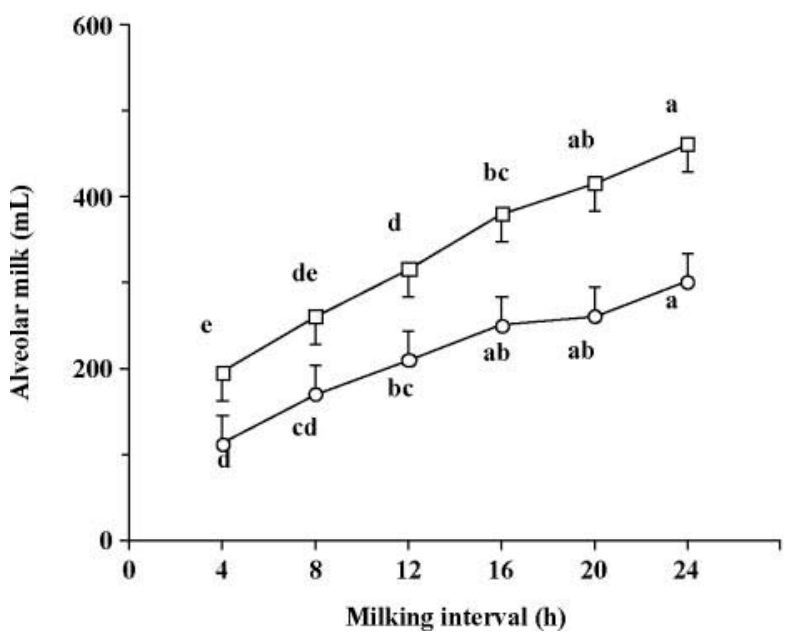

Figure 1. Changes in volumes of (a) cisternal milk, and (b) alveolar milk in Manchega ( $($ ) and Lacaune ( $\square$ ) ewes at different milking intervals. Percentages of cisternal milk of total milk in the udder of Manchega (-o-) and Lacaune $(-\square-)$ ewes are shown as dotted lines. Values are least squares means. Vertical bars represent SEM; ${ }^{a-f}$ Means within the same breed with different letters differ at $P<$ 0.05 .

volume of milk left when measuring the alveolar milk fraction.

As expected, cisternal milk percentages were different $(P<0.01)$ between breeds. The contribution of cisternal milk to total milk in the udder represented 53 and $68 \%$ in Manchega and Lacaune ewes, respectively. Values were greater in Lacaune (47 to 77\%) than in Manchega (33 to 65\%) throughout the milking intervals (4 to 24 h). Percentages of cisternal milk obtained in Manchega ewes were similar to McKusick et al. (2002) in East Friesian crossbred dairy ewes (32 to 57\%) for a similar milking interval range ( 4 to $24 \mathrm{~h}$ ). On the other hand, percentage of cisternal milk in Lacaune ewes was high and close to that observed in Sarda ewes (82\%) for a 24-h milking interval (Nudda et al., 2000). Moreover, the Sarda value may have been overestimated because the authors used adrenaline instead of atosiban to avoid spontaneous milk letdown.

With these differences in mind, dairy sheep breeds could be classified according to their udder cistern features: the large-cisterned ewes (e.g., Awassi, Lacaune, and Sarda), usually selected for high milk yield, present a great capacity of milk storage in the cisternal compartment, and the medium-cisterned ewes (e.g., East Friesian crossbred and Manchega), which have been selected as dual-purpose or local breeds, show a medium capacity for storing milk inside the cisterns (Labussière, 1988). Small-cisterned ewe breeds usually correspond to unselected or nondairy sheep.

Percentages of cisternal milk obtained for dairy ewes (Figure 1a, dotted lines) were greater than values reported in Ripollesa meat sheep (24\% at 4 h; Caja et al., 1999), but close to those in Murciano-Granadina goats (75\% to 24 h; Salama et al., 2004). Consequently, efficient udder stimulation in dairy sheep does not seem to be a key to maximizing machine-milking fraction and minimizing stripping fraction during milking.

Percentages of cisternal milk increased $(P<0.05)$ with time after milking and reached the maximum at $24 \mathrm{~h}$, although values did not differ from 16 to $20 \mathrm{~h}$ in Manchega and from 12 to $24 \mathrm{~h}$ in Lacaune ewes (Figure 1a). A similar evolution pattern of cisternal milk percentage with increasing milking interval was found by McKusick et al. (2002) in East Friesian crossbred ewes, which had the maximum percentage of cisternal milk at $24 \mathrm{~h}$ but did not show differences between 12 and $20 \mathrm{~h}$ of udder filling. Experiments in dairy goats (Salama et al., 2004) showed that the ability to tolerate extended milking intervals was related to the size of cisternal compartment. Thus, animals that store a larger proportion of milk in the gland cistern were able to tolerate extended milking intervals better than those that stored a relatively larger proportion in the alveolar compartment. In our experiment, greater percentages of cisternal milk were detected in Lacaune than in Manchega (Figure 1a), so smaller milk losses were expected in Lacaune than in Manchega ewes when once daily milking is performed. Nudda et al. (2002) reported moderate milk yield losses in Awassi (18\%) and Sarda (24\%) ewes when a 24-h milking interval was applied for only $4 \mathrm{~d}$ in mid lactation. Salama et al. (2003) reported an 18\% milk yield loss in dairy goats milked once daily throughout lactation. Studies on the long-term effect of once-daily milking have been inadequate in dairy ewes, so further research is necessary to support the hypothesis of applying long-term reduced milking frequencies (e.g., once-daily milking) in large-cisterned dairy ewes. 
Transfer of milk from the alveoli to the cistern seemed to start very soon after milking (Figure 1), without requiring that the alveolar compartment reach a saturation stage, which is consistent with early observations in dairy ewes (McKusick et al., 2002) and dairy goats (Salama et al., 2004). In our results, milk transfer from alveolar tissue to cistern according to time after milking appeared to occur in different ways by breed. From the 4-h milking interval, Manchega and Lacaune ewes differed $(P<0.05)$ in cisternal $(57$ vs. $161 \mathrm{~mL}$, respectively; SEM, $53 \mathrm{~mL}$ ) and alveolar (98 vs. $182 \mathrm{~mL}$, respectively; SEM, $38 \mathrm{~mL}$ ) milk compartments, and the differences were maintained until $24 \mathrm{~h}$ (Figure 1a). The cisternal:alveolar ratio at the 24 -h milking interval was 2.0:1 and 3.4:1 for Manchega and Lacaune ewes, respectively. McKusick et al. (2002) reported values in East Friesian crossbred ewes that were greater for alveolar milk at the 4-h milking interval, supporting a large and baggy udder, although cisternal:alveolar ratios at $24 \mathrm{~h}$ were lower (1.4:1) than in our results. These results confirm the importance of the cisternal compartment in accommodating milk storage when the milking interval is extended in dairy ewes, allowing significant increments of total milk yield until 24 -h of udder filling.

\section{Cisternal Scans}

During ultrasonography, milk in the gland cistern was evident in the scans (Figure 2) as a dark area (anechogenic) and the glandular parenchyma as a graywhite area (echogenic), in agreement with other works carried out in ewes, goats, and cows (Bruckmaier and Blum, 1992; Ruberte et al., 1994). No differences were detected between left and right half udder cisternal areas in the dairy ewes $\left(23.18 \pm 0.74 \mathrm{~cm}^{2}\right)$, probably because experimental ewes were selected based on udder symmetry, and machine milking may have contributed to the udder symmetry maintenance. Therefore, left and right udder half values were averaged and discussed jointly.

Manchega and Lacaune ewes differed significantly ( $P$ $<0.001$ ) in cistern area values (Figure 3). Cistern area value for Manchega ewes was $52 \%$ lower $(P<0.001)$ than for Lacaune ewes (mean of all the milking intervals; Manchega: $15.01 \pm 1.00 \mathrm{~cm}^{2}$ and Lacaune: 31.36 $\left.\pm 1.00 \mathrm{~cm}^{2}\right)$. Other values of cisternal area in sheep are those obtained in East Friesian (Bruckmaier and Blum, 1992; Bruckmaier et al., 1997; 19 to $40 \mathrm{~cm}^{2}$ ), Sarda (Nudda et al., 2000; $19 \mathrm{~cm}^{2}$ ), Lacaune (Bruckmaier et al., 1997; $33 \mathrm{~cm}^{2}$ ), and Ripollesa (Caja et al., 1999; 5.6 $\mathrm{cm}^{2}$ ). Differences in sheep breed, stage of lactation, and hours of udder filling could explain the large variability among the studies cited. Our results confirm the importance of the cisternal compartment in dairy ewes (Manchega: 4 to $21 \mathrm{~cm}^{2}$; Lacaune: 16 to $38 \mathrm{~cm}^{2}$, for 4 and 24-h intervals, respectively), especially in Lacaune ewes, which presented cisternal areas greater than those of Murciano-Granadina dairy goats $\left(9\right.$ to $28 \mathrm{~cm}^{2}$ for 8- and 24-h interval; Salama et al., 2004).

Values and changes in cisternal area were affected $(P<0.001)$ by milking intervals (Figure 3$)$. Cisternal areas showed curvilinear increases with milking interval, reaching a plateau at $20 \mathrm{~h}$. These plateaus could be controversial because the cisternal milk volume increased linearly up to 24-h interval in both breeds. We hypothesize that either the frequency probe used (5 $\mathrm{MHz})$ or the exploration depth $(14 \mathrm{~cm})$ was not optimum for visualizing the full extent of the cisternal-cross section in the scan at extended milking intervals.
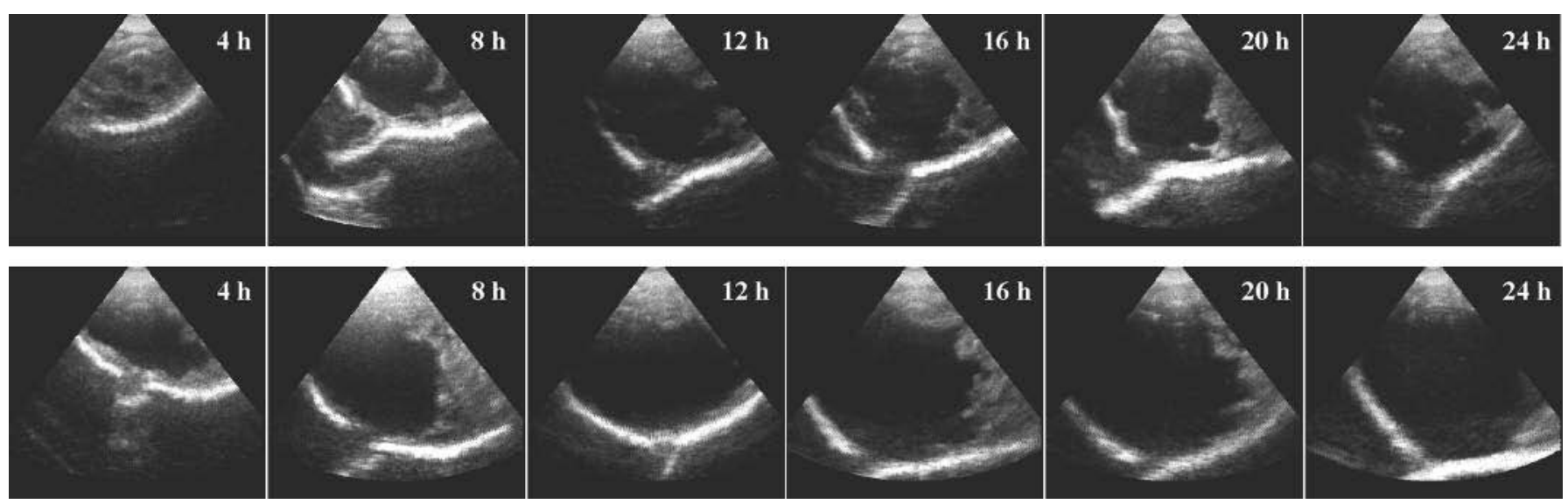

Figure 2. Cisternal scans of the left half cistern of a Manchega (top row) and a Lacaune (bottom row) ewes at different milking intervals. Udder cisterns filled with milk appear as dark areas and the glandular parenchyma as gray-white areas. 
Table 1. Correlations between cisternal area and different milk fractions in Manchega (above diagonal) and Lacaune (below diagonal) dairy ewes milked at $4,8,12,16,20$, and $24 \mathrm{~h}$ of milking interval

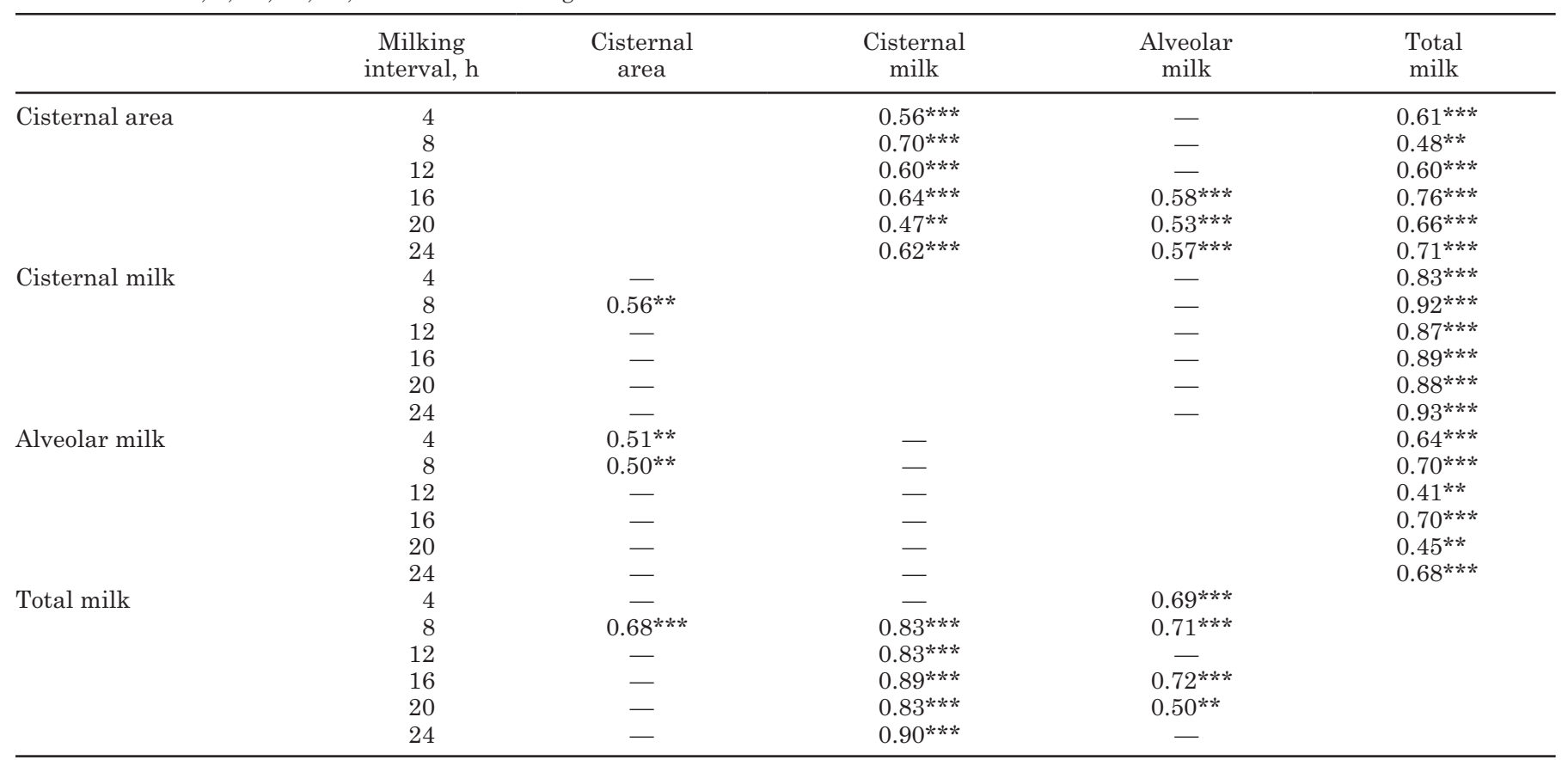

${ }^{* *} P<0.05 ;{ }^{* * *} P<0.01$.

\section{Relationship Between Cisternal Area and Milk Fractions}

Correlations between cisternal area, and cisternal, alveolar and total milk were calculated for all the milking intervals tested (Table 1). Manchega and Lacaune ewes presented the greatest correlations between cisternal area and cisternal milk at the 8-h interval (Manchega, $\mathrm{r}=0.70, P<0.001$; Lacaune, $\mathrm{r}=0.56, P$ $<0.05$ ), which were similar to those reported by Rovai (2001) in the same breeds (Manchega, $r=0.89$; and Lacaune, $r=0.57$ ) and to those reported in dairy goats ( $r=0.72$ at 8 h; Salama et al., 2004), but lower than correlations reported in meat sheep $(r=0.90$ at $4 \mathrm{~h}$; Caja et al., 1999).

In Manchega ewes, cisternal area positively correlated with volume of cisternal milk at all the milking intervals $(\mathrm{r}=0.47$ to $0.70 ; P<0.05)$, whereas in Lacaune ewes, correlation was only significant at the 8 -h interval $(\mathrm{r}=0.56, P<0.05)$. The greater cisternal volumes presented by Lacaune ewes and the use of a $5-\mathrm{MHz}$ sectorial probe with only $14 \mathrm{~cm}$ of exploration depth could be the cause of the low correlations observed in this breed when extended milking intervals were applied. Nudda et al. (2000) reported a correlation $(\mathrm{r}=0.82 ; 24 \mathrm{~h}$ after milking) in large-cisterned Sarda dairy ewes using a $3.5-\mathrm{MHz}$ linear probe, which gives a deeper and wider exploration field and allowed better correlations at the longer milking intervals.
Correlation coefficients between cisternal area and total milk yield varied according to breed and were less in Lacaune than in Manchega ewes (Table 1). Values in Manchega ranged between 0.48 and 0.76 , indicating that udder cistern size was related to the amount of milk produced, and that ultrasonography could be used to identify high-yielding animals in this breed. In Lacaune ewes, correlation coefficients were only signifi-

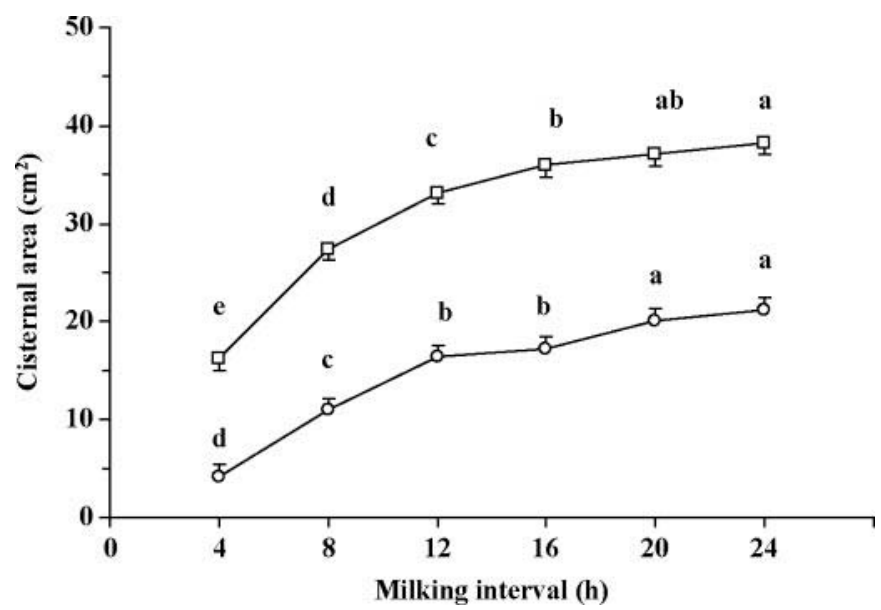

Figure 3. Changes in cisternal area of mammary udder measured by ultrasonography in Manchega ( $($ ) and Lacaune ( $\square$ ) ewes at different milking intervals. Values are least squares means of half udders. Vertical bars represent SEM; ${ }^{a-e}$ Means within the same breed with different letters differ at $P<0.05$. 
(a)

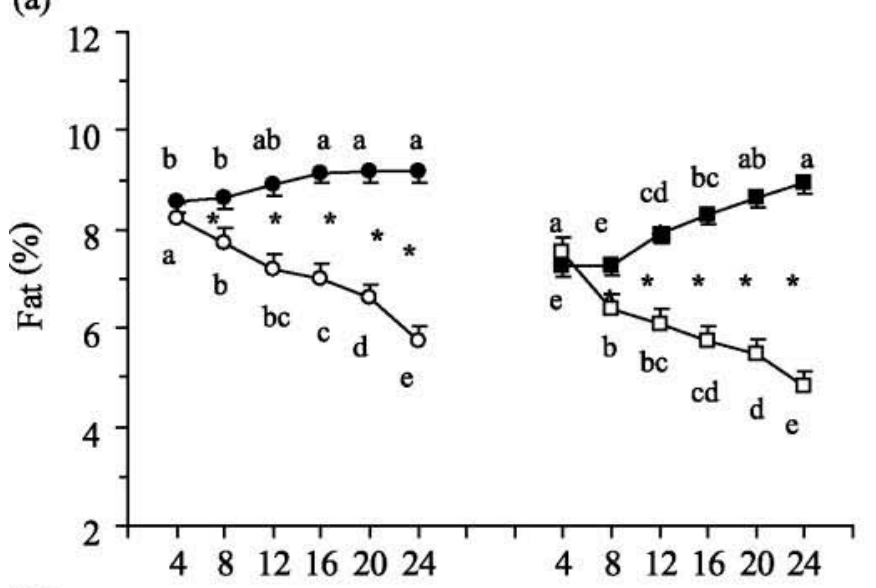

(b)

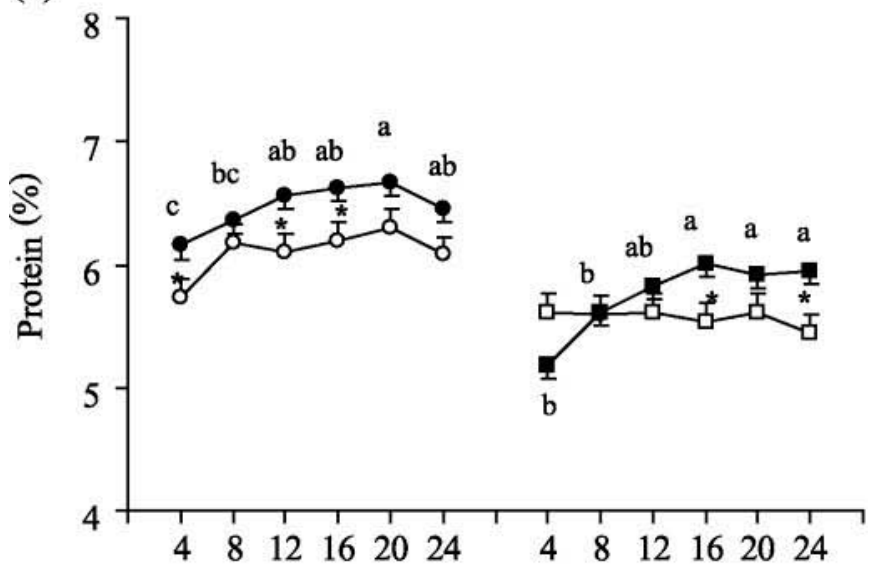

(c)

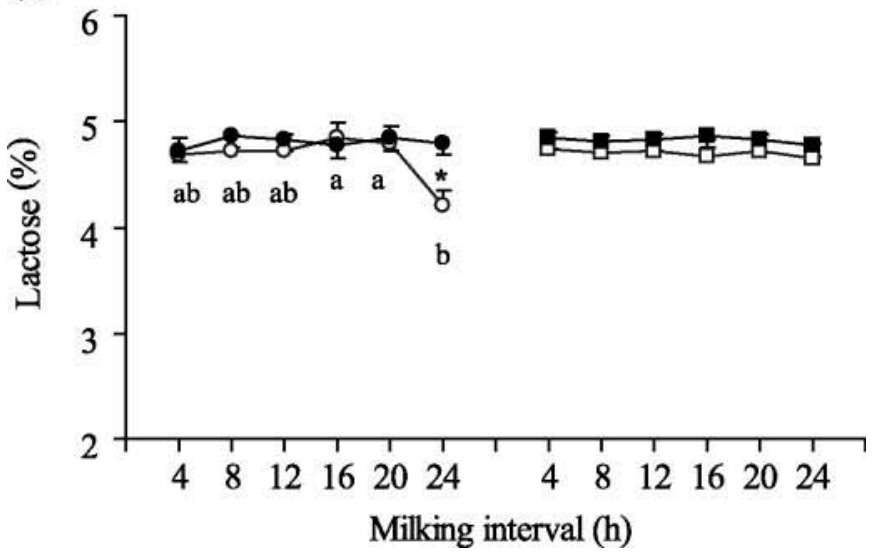

Figure 4. Changes in (a) fat, (b) protein, and (c) lactose contents for cisternal (in white) and alveolar (in black) milk fractions for different milking intervals in Manchega $(\circ, \bullet)$ and Lacaune $(\square, \boldsymbol{\bullet})$ dairy ewes. Values are least squares means. Significant differences between alveolar and cisternal fractions within a time category are indicated by * $(P<0.05)$. Vertical bars represent SEM; ${ }^{\text {a-e }}$ Means within the same breed with different letters differ at $P<0.05$.

cant at the 8 -h interval $(\mathrm{r}=0.68 ; P<0.01)$, showing the methodological problem indicated above with regard to probe depth. In both breeds, volumes of milk fractions (cisternal and alveolar) correlated with total milk yield in all the milking intervals (Manchega, $\mathrm{r}=0.41$ to 0.93; Lacaune, $r=0.50$ to 0.90 ; Table 1 ).

\section{Composition of Milk Fractions}

Percentage of fat in cisternal and alveolar fractions varied inversely at different milking intervals (Figure 4a). Fat content of milk fractions was affected by breed $(P<0.001)$, and was always greater in Manchega than in Lacaune ewes. Fat percentage in cisternal milk dramatically decreased $(P<0.05)$ as milking interval increased (Manchega, $-30 \%$; Lacaune, $-36 \%$; between 4- and 24-h milking intervals). Conversely, milk fat content in alveolar milk increased $(P<0.05)$ as milking interval increased, but reached a plateau at $12 \mathrm{~h}$ of udder filling in Manchega (8.9\% on average) and at $20 \mathrm{~h}$ in Lacaune (8.7\% on average). The data confirm that transfer of milk fat from the alveoli to the cistern slowed with the increase in milking interval, producing a backup of milk fat in the alveolar compartment, as described previously in ewes (McKusick et al., 2002). Fat content in alveolar milk was greater $(P<0.05)$ than the percentage of fat in cisternal milk for most milking intervals studied (Manchega, 8.55 to $9.16 \%$ vs. 8.24 to $5.74 \%$; Lacaune, 7.26 to $8.93 \%$ vs. 7.54 to $4.84 \%$, respectively), except for the 4 -h interval. The large size of fat globules in conjunction with the active expulsion required for their drainage to the cistern favored their accumulation in the alveolar compartment. Thus, milk fat concentration was usually lower in cisternal than in alveolar milk in dairy ewes (Labussière, 1969; Rovai, 2001).

Milk protein and lactose contents were slightly affected by milking interval (Figure $4 \mathrm{~b}$ and $4 \mathrm{c}$ ). Milk protein content was greater $(P<0.001)$ in Manchega than in Lacaune ewes in both cisternal $(6.10 \pm 0.09$ vs. $5.57 \pm 0.09 \%$, respectively) and alveolar milk (6.47 \pm 0.08 vs. $5.82 \pm 0.08 \%$, respectively) fractions. As the milking interval increased, the protein content of the cisternal milk fraction was not modified (Manchega, $6.10 \pm 0.10 \%$; Lacaune, $5.57 \pm 0.09 \%$ ), but protein content did increase in alveolar milk, remaining constant after the 12-h interval (Manchega, $6.56 \pm 0.11 \%$; Lacaune, $5.83 \pm 0.11 \%)$. No significant differences were observed between milk protein percentage of cisternal and alveolar milk (Manchega: 6.10 vs. $6.47 \%$, SEM, 0.09; Lacaune: 5.57 vs. $5.82 \%$, SEM, 0.09; $P>0.05$; respectively), which may be because milk protein is found primarily in the form of small casein micelles (Cowie and Tindal, 1971) within the aqueous fraction of milk. Thus, proteins pass freely from the alveolar to the cistern compartment without being as dependent on milk ejection reflex as is fat content. Nevertheless, at 


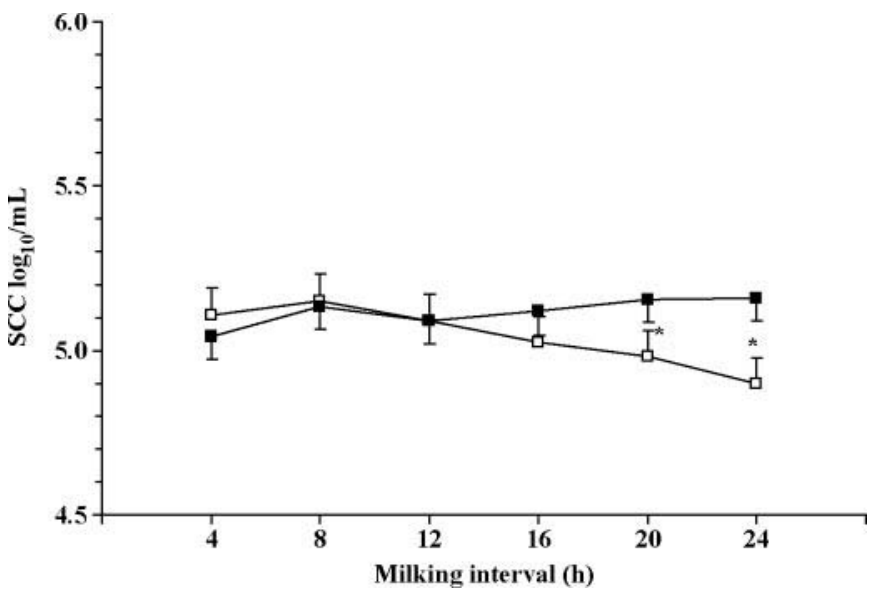

Figure 5. Changes in SCC within cisternal () and alveolar (ロ) milk at different milking intervals. Values are least squares means of Manchega and Lacaune ewes. Significant differences between alveolar and cisternal fractions within a time category are indicated by * $(P<0.05)$. Vertical bars represent SEM.

some milking intervals, we found a small increment of protein content in the alveolar fraction compared with the cisternal fraction. McKusick et al. (2002) observed differences of milk protein percentages between cisternal and alveolar fractions in East Friesian crossbred ewes, but only at the 24-h interval.

With respect to milk lactose, milking interval and breed did not affect lactose content either in alveolar or in cisternal milk, except at the 24-h interval, when a significant difference between cisternal and alveolar milk (4.20 vs. $4.79 \%, P<0.001$; respectively) was observed only in Manchega ewes, indicating that Manchega ewes should suffer greater milk yield losses than Lacaune ewes at the 24-h milking interval. Decreased lactose percentage associated with longer milking intervals may be due to leaky tight junctions between mammary epithelial cells. When mammary tight junctions were disrupted, the small lactose molecules passed freely from milk to blood (Stelwagen et al., 1994) and the influx of interstitial fluid into the milk occurred (Stelwagen et al., 1997). Both events probably favored important changes in milk osmosis, provoking the decrease of lactose content observed in cisternal milk of Manchega ewes. Lactose content in alveolar milk did not vary according to milking interval and breed. Content of total solids showed a similar trend to milk fat content (data not shown).

Intramammary infections were not observed during the experiment. Both breeds showed low SCC in alveolar $\left(131 \times 10^{3}\right.$ cells $\left./ \mathrm{mL}, P=0.74\right)$ and cisternal milk fractions $\left(110 \times 10^{3}\right.$ cells $\left./ \mathrm{mL}, P=0.46\right)$. Moreover, milking interval had no effect $(P>0.10)$ on SCC in either breed. Regardless of milk fractions, SCC con- tent was similar between cisternal and alveolar milk when 4-, 8-, and 12-h intervals were performed. Yet alveolar milk had a greater SCC $(P<0.05)$ at 20 and $24 \mathrm{~h}$ (Figure 5). Similar results were obtained in milk fractions of East Friesian crossbred ewes (McKusick et al., 2002). Taking into account that the impairment of tight junctions starts from $20 \mathrm{~h}$ of udder filling in dairy ewes (Castillo et al., 2008), tight junction disruption might have facilitated a paracellular influx of somatic cells into milk (Stelwagen and Lacy-Hulbert, 1996), provoking the differences observed between cisternal and alveolar milk fractions from $20 \mathrm{~h}$ after milking.

\section{CONCLUSIONS}

Medium- and high-yielding dairy ewes such as Manchega and Lacaune were able to adapt to an extended milking interval by increasing the milk volume stored in their cisternal compartment. Both breeds were capable of storing large amounts of milk within the cisterns and presented a pattern of milk distribution similar to dairy goats. Nevertheless, differences in milk fractioning and cisternal size were detected between the 2 breeds. High-yielding Lacaune ewes presented greater cisternal milk percentages and greater cisternal areas, and were able to store larger volumes of cisternal milk than the medium-yielding Manchega ewes, suggesting easier adaptation of large-cisterned Lacaune ewes to lesser milking frequencies. On the other hand, ultrasonography was useful for evaluating changes in cisternal milk according to time after milking and for identifying large-cisterned ewes. In both breeds, the 8-h milking interval provided a more consistent estimation of the udder cistern size by ultrasonography, so this interval is proposed when an estimation of the udder cistern size is desired in dairy ewes.

\section{ACKNOWLEDGMENTS}

This work is part of a CICYT research project (AGL2002-03472) of the Spanish Ministry of Science and Technology. The authors are grateful to Ramon Costa and the team of the SGCE (Servei de Granges i Camps Experimentals) of the Universitat Autònoma de Barcelona for the care of the animals, and to Nic Aldam for the English revision of the manuscript.

\section{REFERENCES}

Ayadi, M., G. Caja, X. Such, and C. H. Knight. 2003. Use of ultrasonography to estimate cistern size and milk storage at different milking intervals in the udder of dairy cows. J. Dairy Res. 70:1-7.

Bruckmaier, R. M., and J. W. Blum. 1992. B-Mode ultrasonography of mammary glands of cows, goats and sheep during $\alpha$ - and 
B-adrenergic agonist and oxytocin administration. J. Dairy Res. 59:151-159.

Bruckmaier, R. M., G. Paul, H. Mayer, and D. Schams. 1997. Machine milking of Ostfriesian and Lacaune dairy sheep: Udder anatomy, milk ejection and milking characteristics. J. Dairy Res. 64:163172.

Caja, G., M. Ayadi, and C. H. Knight. 2004. Changes in cisternal compartment based on stage of lactation and time since milk ejection in the udder of dairy cows. J. Dairy Sci. 87:2409-2415.

Caja, G., X. Such, J. Ruberte, A. Carretero, and M. Navarro. 1999. The use of the ultrasonography in the study of the mammary gland cisterns during lactation in sheep. Pages 91-96 in Milking and Milk Production of Dairy Sheep and Goats. EAAP Publication no. 95. Wageningen Pers, Wageningen, the Netherlands.

Castillo, V., X. Such, G. Caja, R. Casals, E. Albanell, and A. A. K. Salama. 2008. Effect of milking interval on milk secretion and mammary tight junction permeability in dairy ewes. J. Dairy Sci. 91:2299-2306

Cowie, A. T., and J. S. Tindal. 1971. The Physiology of Lactation. Camelot Press Ltd., London, UK.

Davis, S. R., V. C. Farr, P. J. A. Copeman, V. R. Carruthers, C. H. Knight, and K. Stelwagen. 1998. Partitioning of milk accumulation between cisternal and alveolar compartments of the bovine udder: Relationship to production loss during once daily milking. J. Dairy Res. 65:1-8.

Dewhurst, R. J., and C. H. Knight. 1994. Relationship between milk storage characteristics and the short-term response of dairy cows to thrice-daily milking. Anim. Prod. 58:181-187.

Labussière, J. 1969. Importance, composition et signification des différentes fractions de lait obtenues successivement au cours de la traite mécanique des brebis. Ann. Zootech. 18:185-196.

Labussière, J. 1988. Review of physiological and anatomical factors influencing the milking ability of ewes and the organization of milking. Livest. Prod. Sci. 18:253-274.

Lollivier, V., and P. G. Marnet. 2005. Galactopoietic effect of milking in lactating Holstein cows: Role of physiological doses of oxytocin. Livest. Prod. Sci. 95:131-142.

McKusick, B. C., D. L. Thomas, Y. M. Berger, and P. G. Marnet 2002. Effect of milking interval on alveolar versus cisternal milk accumulation and milk production and composition in dairy ewes. J. Dairy Sci. 85:2197-2206.
Nudda, A., R. Bencini, S. Mijatovic, and G. Pulina. 2002. The yield and composition of milk in Sarda, Awassi, and Merino sheep milked unilaterally at different frequencies. J. Dairy Sci. 85:2879-2884.

Nudda, A., G. Pulina, R. Vallebella, R. Bencini, and G. Enne. 2000. Ultrasound technique for measuring mammary cistern size of dairy ewes. J. Dairy Res. 67:101-106.

Rovai, M. 2001. Caracteres morfológicos y fisiológicos que afectan la aptitud al ordeño mecánico en ovejas de raza Manchega y Lacaune. PhD Thesis. Autònoma de Barcelona Univ., Bellaterra. http://www.tesisenxarxa.net/TESIS UAB/AVAILABLE/TDX 0226102-145915

Ruberte, J., A. Carretero, M. Fernández, M. Navarro, G. Caja, F. Kirschner, and X. Such. 1994. Ultrasound mammography in the lactating ewe and its correspondence to anatomical section. Small Rumin. Res. 13:199-204.

Salama, A. A. K., G. Caja, X. Such, S. Peris, A. Sorensen, and C. H. Knight. 2004. Changes in cisternal udder compartment induced by milking interval in dairy goats milked once or twice daily. J. Dairy Sci. 87:1181-1187.

Salama, A. A. K., X. Such, G. Caja, M. Rovai, R. Casals, E. Albanell, M. P. Marín, and A. Martí. 2003. Effects of once versus twice daily milking throughout lactation on milk yield and milk composition in dairy goats. J. Dairy Sci. 86:1673-1680.

Stelwagen, K., S. R. Davis, V. C. Farr, and S. J. Eichler. 1994. Effect of once daily milking and concurrent somatotropin on mammary tight junction permeability and yield of cows. J. Dairy Sci. 77:2994-3001.

Stelwagen, K., V. C. Farr, H. A. McFadden, C. G. Prosser, and S. R. Davis. 1997. Time course of milk accumulation-induced opening of mammary tight junctions and blood clearance of milk components. Am. J. Physiol. 273:R379-R386.

Stelwagen, K., and S. J. Lacy-Hulbert. 1996. Effect of milking frequency on milk somatic cell count characteristics and mammary secretory cell damage in cows. Am. J. Vet. Res. 57:902-905.

Wellnitz, O., R. M. Bruckmaier, C. Albrecht, and J. W. Blum. 1999. Atosiban, an oxytocin receptor blocking agent: Pharmacokinetics and inhibition of milk ejection in dairy cows. J. Dairy Res. 66:18. 